TECHNICAL TRANSACTIONS 1/2019

ARCHITECTURE AND URBAN PLANNING

DOI: $10.4467 / 2353737$ XCT.19.003.10043

SUBMISSION OF THE FINAL VERSION: 27/11/2018

\author{
Ewa Łużyniecka (iD) orcid.org/0000-0001-9664-0720 \\ ewa.luzyniecka@pwr.edu.pl \\ Faculty of Architecture, Wrocław University of Technology
}

\title{
ARCHITECTURE OF MEDIEVAL BREWERIES IN CISTERCIAN ABBEYS
}

\section{ARCHITEKTURA ŚREDNIOWIECZNYCH BROWARÓW \\ W OPACTWACH CYSTERSKICH}

\begin{abstract}
The paper presents some conclusions regarding the architectureof medieval breweries in selected Cistercian abbeys. The conclusions have been formulated on the basis of research of Cistercian monasteries in Poland, Germany, and the Czech Republic, as well as recently in France, which have been conducted for 30 years by the author.The main observation is that there are very few original structures like these which were built in the Middle Ages. Another conclusion regards the location of breweries within the area of the monasteries. The rule was to build them by watercourses either away from the centre of the abbeys or by the western wings of cloistral buildings. The examples presented in the paper also confirm the thesis known from previous publications, namely that the architecture of monastic breweries, on the one hand, reflected the economic situation of the abbey and, on the other, the time and style as well as the region where it was established. Keywords: brewery, medieval, abbey, Cistercians
\end{abstract}

\section{Streszczenie}

W artykule przedstawiono kilka wniosków dotyczących architektury średniowiecznych browarów w wybranych opactwach cysterskich. Wnioski te zostaly sformulowane na podstawie prowadzonych przez autorkę od 30 lat badań klasztorów cysterskich w Polsce, Niemczech i Czechach oraz ostatnio we Francji. Głównym spostrzeżeniem jest to, że przetrwało do dziś bardzo niewiele tego typu budowli z czasu średniowiecza. Następny wniosek dotyczy lokalizacji browarów w obrębie murów klasztornych. Zasadą było budowanie ich przy ciekach w dwojaki sposób: w oddaleniu od centrum opactwa lub przy zachodnich skrzydlach budynków klauzur. Zaprezentowane w artykule przykłady potwierdzily także znaną z dotychczasowych opracowań tezę, że architektura browarów klasztornych była odzwierciedleniem z jednej strony pozycji ekonomicznej opactwa, $\mathrm{z}$ drugiej strony czasu i stylu oraz rejonu, w którym powstawał. 


\section{Introduction}

The history of beer production goes back to ancient times and it probably began when people started to grow crops. The beer which was produced then greatly differed from the beer produced now - it had very little alcohol, it was less clear, and it was highly calorific and nutritious. It was the Babylonians who started to add hops to improve the taste of beer and to conserve it further. Beer was the main component of diet along with bread in ancient Egypt [1, p. 34].

The nutritious value of beer was equally significant in the Middle Ages. Its production was popular in monasteries, lord's and prince's courts, and in towns. Until the $12^{\text {th }}$ century, the right to brew beer was reserved almost exclusively to monasteries. They brewed beer mainly for their own needs but they would also use beer or hops as a legal tender or trade it. Monks were famous for their continuous improvement of beer production technology and developing new recipes. Some abbeys were willingly investing; for instance, there are three breweries and several hop plantations on the plan of the Benedictine abbey of St. Gall (now Switzerland) from 820 [2, p. 117].

When the Cistercians built their first abbeys at the beginning of the $12^{\text {th }}$ century, they also adopted the Benedictine tradition in the area of beer production. Their breweries were then built in every monastery; however, they were not always solid structures and few of them have survived until today. Usually, regarding their formal and technical condition, they could not match the monastic churches and cloistral buildings, and that is why they are not often subject to detailed analysis. The objective of this paper is then to draw more attention to these buildings. The author has been studying these structures for 30 years while doing research on Cistercian monasteries in Poland [3, 4], Germany[5] and the Czech Republic, as well as recently in France [6].

\section{Functional parts}

Just as in the case of monasteries, the layout of breweries in the Middle Ages was closely connected with the basic stage of beer production. These stages consist in processing wheat or barley grains in four basic functional zones: malthouse, millhouse, brewhouse and storage house.

The name malthouse derives from the word used to call sprouting grain.Before itwas transported to the malthouse, it was cleaned with shovels in the open air or sieved through a mesh. Then malt was prepared. The grain was soaked in wooden cisterns or stone troughs to separate husks from starched seed. After draining water from the cisterns or troughs, the grain was spread out on large floors made of fired brick, stone or clay. Every now and then the grain was sprinkled until germination began that is when malt forms and a significant part of starch from the grain changes into sugar [7, p. 52].

Next, the malt is dried in a drying room with one or more kilns. The malt could be dried in different ways. The easiest way was to dry it in a heated room on a floor made of fired brick, clay or stone. The interior of the drying room had to be well heated and the malt was turned 
over several times and sprinkled with water. The malt was sometimes dried directly on clay brick semispherical kilns dug into the ground. Another way of drying malt was on wooden shelves with drilled holes or on grates made of twigs. In the most primitive breweries there was a fireplace under the grates or there was a fireplace in more complex structures on the ground floor with a shaft for hot air going to upper levels and to the shelves with the malt. Sometimes bellows were used to dry and air the grain [7, p. 54].

The malt was then crushed in a millhouse.The milled malt or so called grits was stored or immediately transported to the brewhouse where mashing began. The malt was put into a wooden cistern and soaked with hot water, stirring the mix with special paddles.The mixture was heated up to about $70^{\circ} \mathrm{C}$, pouring in boiling water or throwing in hot stones. The mash which was produced was then released to the trough, sieving it through a layer of straw or poured into a cistern with the use of a scoop. The liquid which was produced was poured into kettles or tuns and boiled again while adding hops.Some tuns or kettles were permanently fixed in basins with fireplaces underneath. Sometimes the kettle was placed on stone pillars with a huge chimney above it [8, p. 187].

After boiling, the malted liquid was poured using a wooden scoop or a gutter to a different vessel to cool off. After the liquid cooled it was poured into a keg or a barrel with the use of a funnel strainer, for instance.Yeast deposits from previous brewing were added to the liquid to induce fermentation - pure yeast was not yet known in the Middle Ages. The fermentation took place in the barrels - until the middle of the $19^{\text {th }}$ century it was so-called high fermentation during which the yeast deposits form on the beer surface. The deposits were then removed to obtain a clearer liquid.

Next, the cleared beer was poured into barrels which were rolled to storage places. The main source of problems for beer was high temperature causing it to sour, and that is why the storage places were often dug in the ground and vaulted. In some cases the storage places had ice chambers to lower the temperature of the air.

\section{Breweries located away from the church or cloistral buildings}

The Cistercian abbeys are complexes of monastic buildings surrounded by walls or fences with different layouts, depending on topographical and hydrological conditions. Breweries were located in different places within the abbeys; however, a general principle can be seen in their location. Some of them were built away from the church or cloistral buildings - the most important buildings of the abbey.

This group includes the brewery in Fountains Abbey (foundation 1132) in England which after the dissolution in 1539 fell into ruin. We only know it from archeological finds [9, pp. $106-105,10]$. The brewery was located south-west of the church or cloistral buildings by a channel going from the south to the north into the monastery's mill stream [11].

According to archaeologists the oldest relic of the brewery was the north and south wall built in 1150-1160 (Fig. 1). The brewery could be entered through a great opening in the south. That opening was walled up in $1220-1247$. At the same time, a new east wall was built 
1

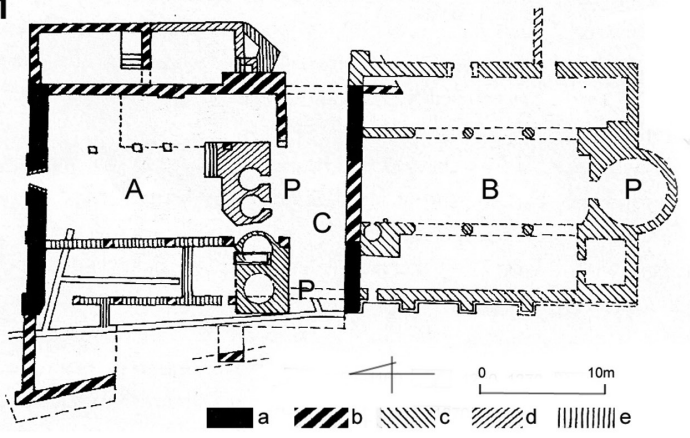

2

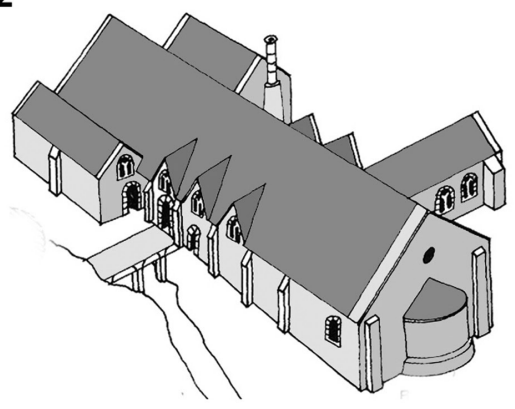

Fig. 1. Fountains, brewery and bakery. 1 - plan per [9, p. 106], 2 - reconstruction per [11, p. 11], A - brewery, B - bakery, C - entrance hall, P - kiln. Walls: a - ca.1150-60, b - ca.1220-1247, c - ca.1260-70, d - end of the $13^{\text {th }}$ century, e $-15^{\text {th }}$ century, developed by E. Eużyniecka

and a three-bay interior was formed. The bays were most probably separated with arcades or columns. According to researchers' dating, a new west wall and north-east annex were built in 1260-1270. At the end of the $13^{\text {th }}$ century, inside the brewery an elevated platform was built with openings for two kettles with chambers for brewing kilns underneath them. At the same time, a bakery witha huge round fireplace was built south of the brewery. According to researchers the brewery was extended again in 1320-1340. This is when another elevated platform with stairs was built. It had two round fireplace chambers with inlets from the south in its lower part. The brewery was last modernized in the $15^{\text {th }}$ century and it included the construction of partition walls between older arcades or columns as well as the south-east annex.

The mediaeval brewery in Lubiąz Abbey in Silesia (foundation 1175) was most probably also located away from the church or cloistral buildings.Its location by a bakery was already known earlier. In about the middle of the $18^{\text {th }}$ century, the Silesian painter Friedrich Bernhard Werner drew an aerial view of the abbey and he described one of the buildings with a Baroque form as Das Back und Brauhaus [12, p. 55] The neoclassical form of the building comes from the $19^{\text {th }}$ century; at present the structure is not used (Fig. 2).

The author studied the brewery at Lubiąż Abbey twenty years ago in search of its mediaeval parts [3, pp. 312-313]. At present, the work's findings are being verified.Jan Kryštofa Lišk presented the mediaeval form of the brewery and the bakery seen from the north in his drawing from 1708 [12, p. 54]. The author drew two two-storied buildings with doublepitched roofs of different heights. This form of the buildings was in general confirmed by architectural research (Fig. 3).

It can be claimed on the basis of those drawings that the brewery in Lubiąż was most probably located in the west part of the present building. Brick walls of two rooms and small, almost semicircular windows were uncovered during research. Furthermore, it was found that the bakery was most probably located in the east part of the building. The most important part of the bakery was a square room witha hemispherical vault with pendentives connected with a chimney located above the fireplace. The relics of the vaults were found during the study. A pointed hip cap carved into the wall of the bakery was also discovered. It served 
1

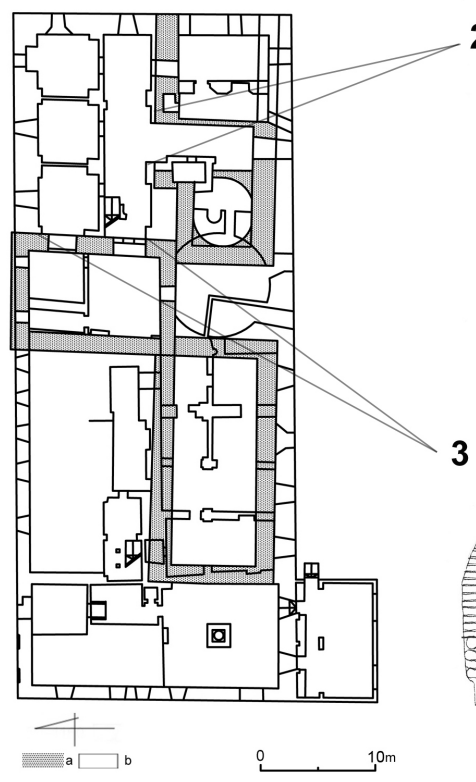

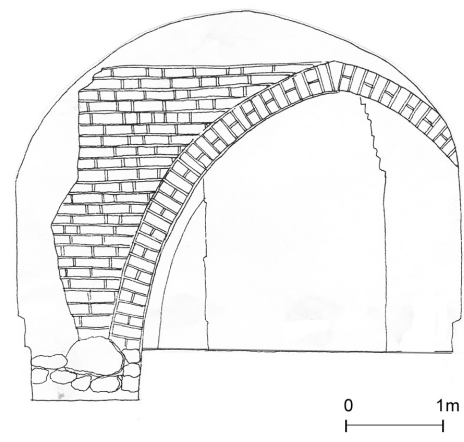

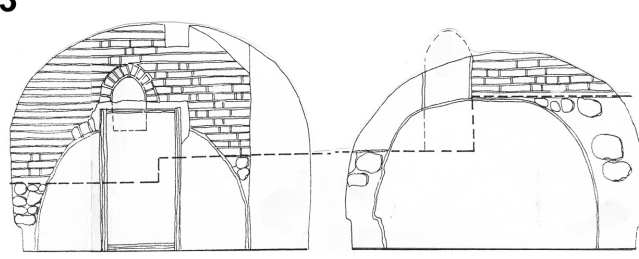

Fig. 2. Lubiąż, brewery and bakery. 1- plan of basements, 2, 3 - building material survey. Walls: a Middle Ages, $\mathrm{b}-17^{\text {th }}-18^{\text {th }}$ century, $\mathrm{c}-19^{\text {th }}$ century, developed by E. Eużyniecka
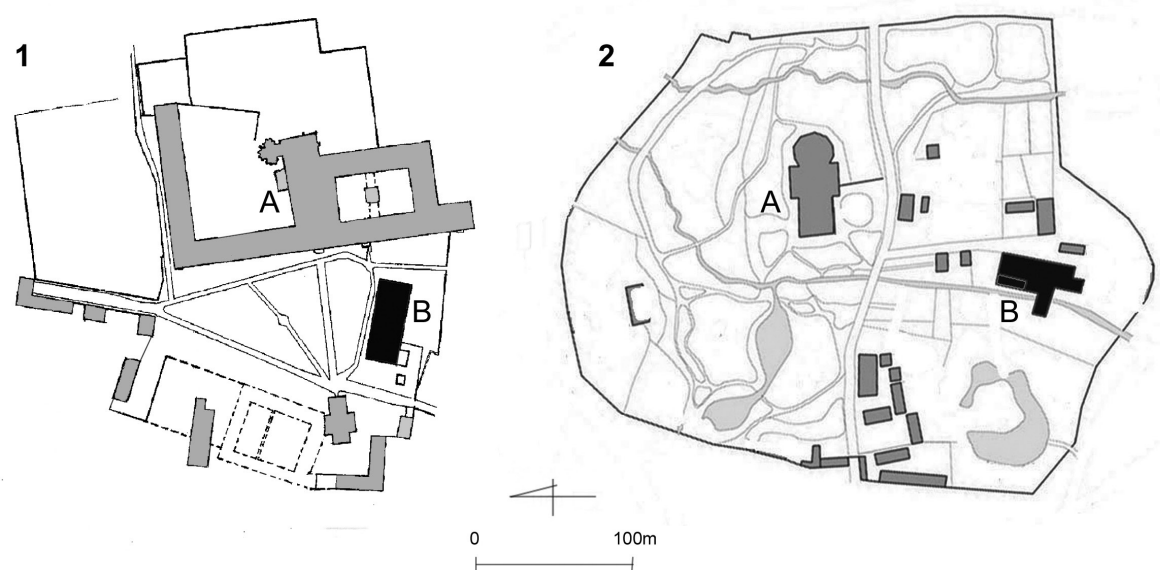

Fig. 3. Breweries located away from the church and the cloistral buildings: 1 - Doberan, 2 - Lubiąż, A - monastic church, B - brewery, developed by E. Łużyniecka

as a buttress for the cracking vault and as an entrance hall to the building. At present, it is difficult to determine the total length and number of buildings of the brewery and the bakery in the Middle Ages because the east buildings were demolished in the $18^{\text {th }}$ century and a wide road was built there. The west buildings were transformed into one structure, changing the direction in which the walls were going. 
Another monastic brewery located away from the church or cloistral buildings is Doberan Abbey in Mecklenburg (foundation 1177) founded in its present site in 1186. The brewery was located south-west of the cloister by a channel going from the south to the north to the monastery's millstream (Fig. 3.2). The building stands out against the other structures of this kind because of the good condition of its mediaeval fabric. Due to its significant dimensions, the building from the $13^{\text {th }}$ and $14^{\text {th }}$ centuries did not need any extension later on. In the $20^{\text {th }}$ century, it burned down several times and at present it does not serve its original function. It has been renovated for many years and seasonal exhibitions are held in some of its interiors.

The author studied the monastery ten years ago [5, pp. 119-131, 458-482] and analysed the operations and the construction of the brewery (Fig. 4). Initially, it was a small building with a fragment of a brick wall being most probably its only original part; it is now inside a structure which has three sections (Fig. 5). The building was remodelled in the $14^{\text {th }}$ century and it housed a malthouse, a brewhouse and a millhouse.

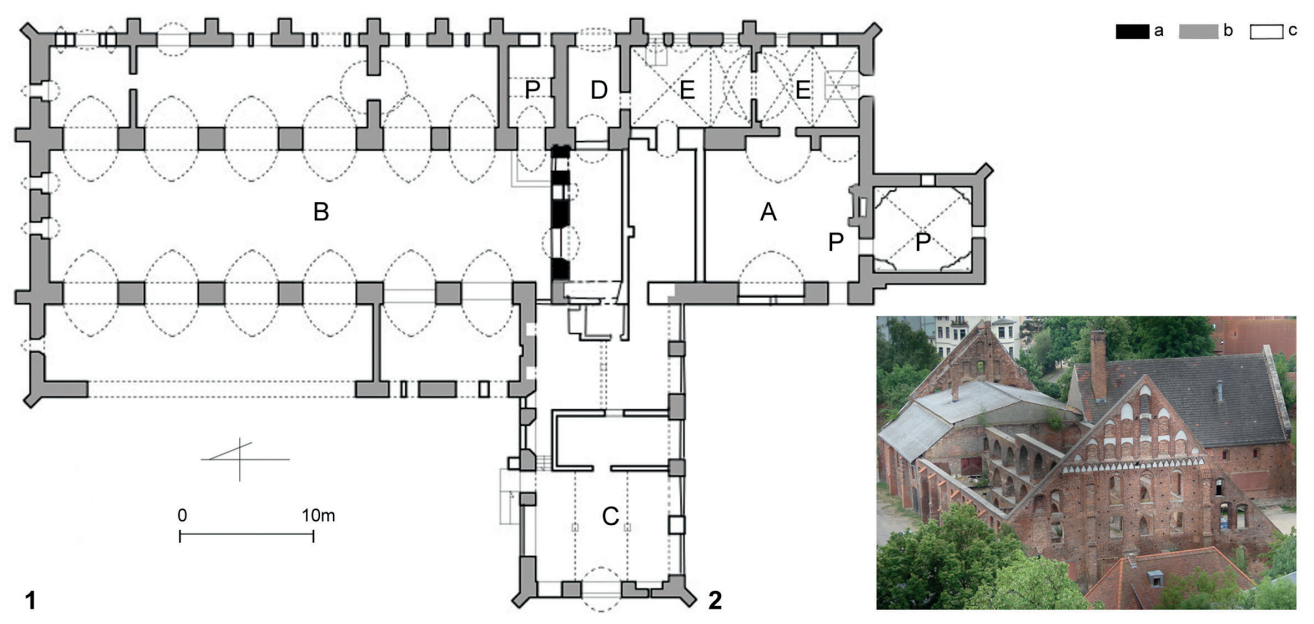

Fig. 4. Doberan, brewery. 1 - plan of basement, 2 - aerial view, 2009, A - malt house, B - brew house, $\mathrm{C}$ - millhouse, D - entrance hall, $\mathrm{E}$ - cooling room and beer storage, $\mathrm{P}$ - kiln, Walls: a - end of the $13^{\text {th }} \mathrm{c} ., \mathrm{b}-14$ th century, $\mathrm{c}-17^{\text {th }}-20^{\text {th }}$ centuries, developed by E. Łużyniecka
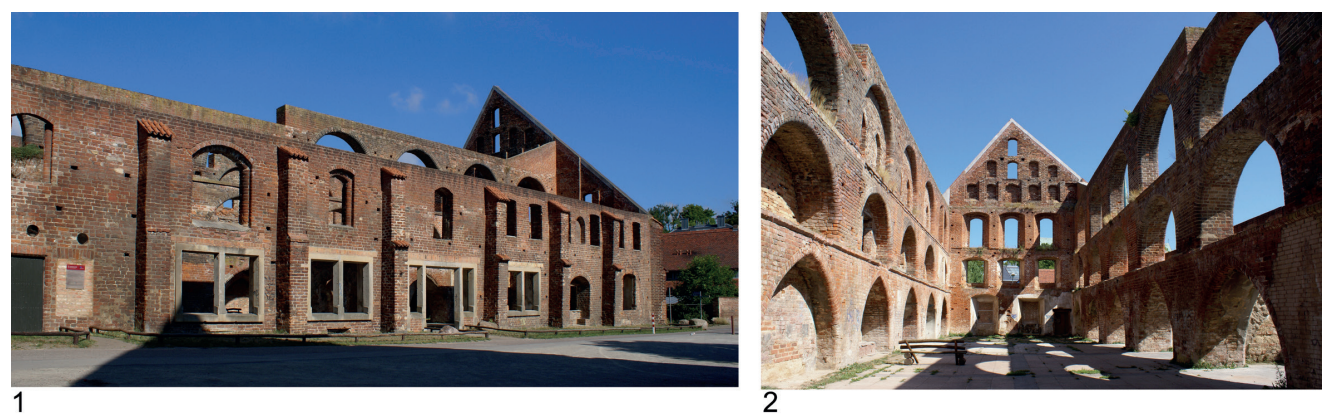

Fig. 5. Brewery in Doberan, 1 - east facade, 2 - brew house interior, 2009, photo by E. Łużyniecka 
All of its load-bearing walls have arches. Depending on the number of stories, there was one, two or three levels of arches. Such a structure was very useful as it allowed for any division of the interior, both horizontal and vertical. The arches in the external walls were filled with thin brick walls so they could be visible only from inside. The flat surfaces of the wall on the outside were reinforced with buttresses.

The central element of the brewery was its entrance hall. One could get south from it to the brewhouse - the remains of the brewing equipment included the traces of fire and a relic of a chimney shaft. The malthouse was north-west of the entrance hall. In the malthouse on the ground floor there was a fireplace with a shaft for hot air provided to the upper stories.

One could also get from the entrance hall to the storage rooms in the south-east part of the building. They were dug into the ground and vaulted. One of them was an ice room called the ice cellar.

Along the axis of the entrance hall there was a millhouse with two milling machines until the $19^{\text {th }}$ century - there were wheels with blades downstairs. At the height of the floor, there were millstones. Malt would be dried and ground on the same level. The excess of crushed malt was most probably stored on the $1^{\text {st }}$ and $2^{\text {nd }}$ floors in the east rooms.

The last example of a structure located away from the church or cloistral buildings is the $14^{\text {th }}$-century brick brewery in Lehnin Abbey in Brandenburg (foundation ca.1180). It was located north of the cloister; beer production stopped there in the $20^{\text {th }}$ century. At present, its interiors are being converted to hold exhibitions and its external walls have been renovated recently [13, p. 62]. During the restauration of the gable walls of the brewery, wide openings with pointed arches were reconstructed at the bottom; narrow windows with pointed arches were reconstructed on two levels at the top. The side walls of the brewery still have their original structure with arches. The walls with narrow, rectangular windows are still visible inside the arches (Fig. 6).
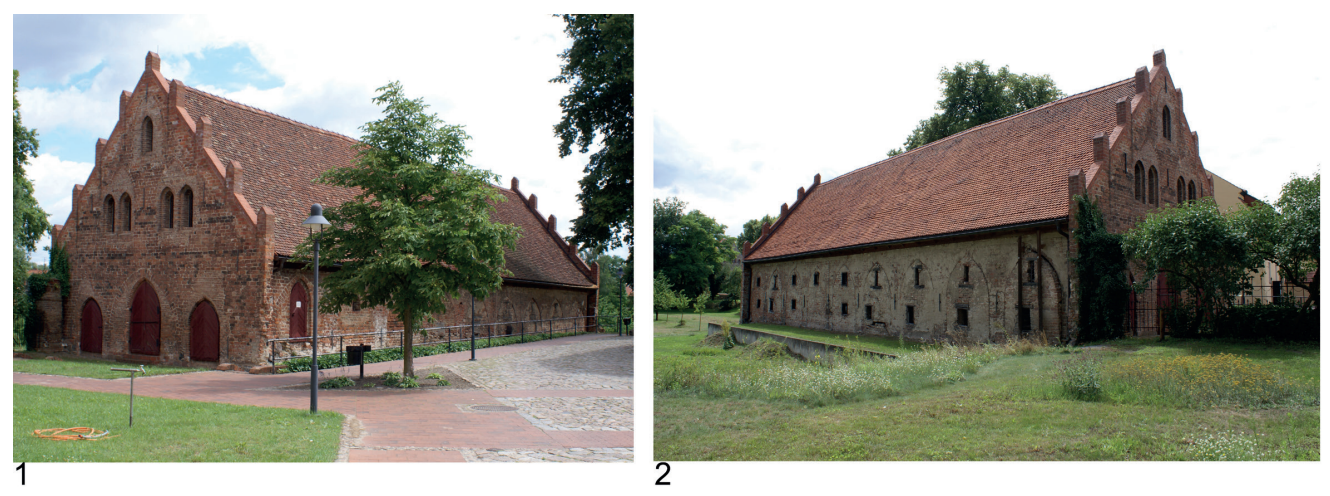

Fig. 6. Brewery in Lehnin, 1 - view from the south-west, 2 - north wall, 2011, photo by E. Łużyniecka 


\section{Breweries located by the cloistral buildings}

The breweries in mediaeval Cistercian abbeys were also sometimes located by the cloistral buildings, close to the west wing called the wing of converts. Sometimes they were built also in front of the west facade of the monastic church.

The brewery of the Pomeranian Cistercian abbey in Oliwa had such a location (foundation 1178-1188) (Fig. 7.1). It no longer exists today but its height can be determined on the basis of the drawing by P. Willer from 1687 and a plan from 1847 [14, p. 39, 44]. At present, a trace of the brewery roof is displayed on the wall of the west towers of today's cathedral in Oliwa.It can be assumed on that basis that the brewery was an exquisite brick building, most probably two-storied. (Fig. 8.1).

The original brewery from the Pomeranian Pelplin Abbey (foundation 1276) no longer exists any more either. The location and the view of that brewery is known from a drawing from 1774 [5, p. 257]. Interestingly, its buildings most probably included a brewhouse and a malthouse located at some distance from it. The brewhouse was most probably located northwest of the cloistral buildings by the yard where beer was bottled and from where it was later taken to the cellars in the west wing of the cloistral buildings. The malthouse was located in the south-west part of the abbey, adjacent to the millhouse and it looked similar to the utility complex from Doberan. It is known from the descriptions from before the demolition in the $19^{\text {th }}$ century that there was a granary with a room for grain storage in the basement. Directly above it there was a malthouse with a special floor to produce malt with high stairs leading to it. Hops and barley were also stored in those buildings.

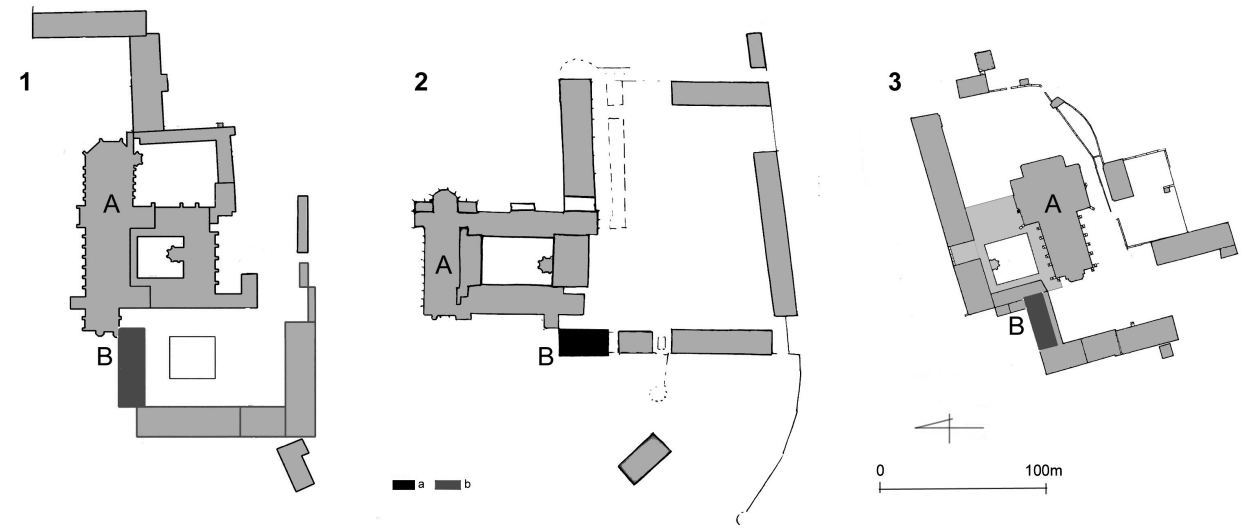

Fig. 7. Breweries by the cloistral buildings, 19th century: 1 - Oliwaper [14, p.44], 2 - Chorinper [15, p.29], 3 - Kamieniec Ząbkowicki acc. to [3, p. 501], A - monastic church, B - brewery, $\mathrm{a}$ - existent building, $\mathrm{b}$ - non-existent building, developed by E. Łużyniecka

The malthouse of the Silesian Kamieniec Ząbkowicki Abbey (foundation 1247) was built right next to the west wing of the cloistral building (Fig. 7.2). Most probably the relics of those buildings are still in the walls of the present residential house. This is evident from the depiction of the malthouse from around the middle of the $18^{\text {th }}$ century by F. B. Werner. 
The author drew three buildings and described them as Maltzhaus, Beckenhs, bräühs [12, p. 80]. In the $19^{\text {th }}$ century, all those buildings were converted and their function changed. The original, mediaeval cellarium in a good condition is still in the west wing of the cloistral building. It has two rooms, dug in the ground a little with a pointed, tunnel vault. They might have been used not only to store food products but also to store beer.

Unlike the buildings described above, which no longer exist, the next brewery is still in a relatively good condition. This is the brewery in Chorin Abbey in Brandenburg (foundation 1258) [15, pp. 44-45]. It is located by the west wing of the building and it adjoins the monastery gate. At present, it does not serve its original function; it is a place to hold exhibitions. It was built in two stages. Its only original, oldest part is the north facade with a tall stepped gable.The facade in the basement is decorated with pointed blanks (Fig. 8.2). The remaining walls of the brewery, built in the $14^{\text {th }}$ century, have a different form. They are flat on the outside, with arches visible only from the inside. The north facade of the brewery differs
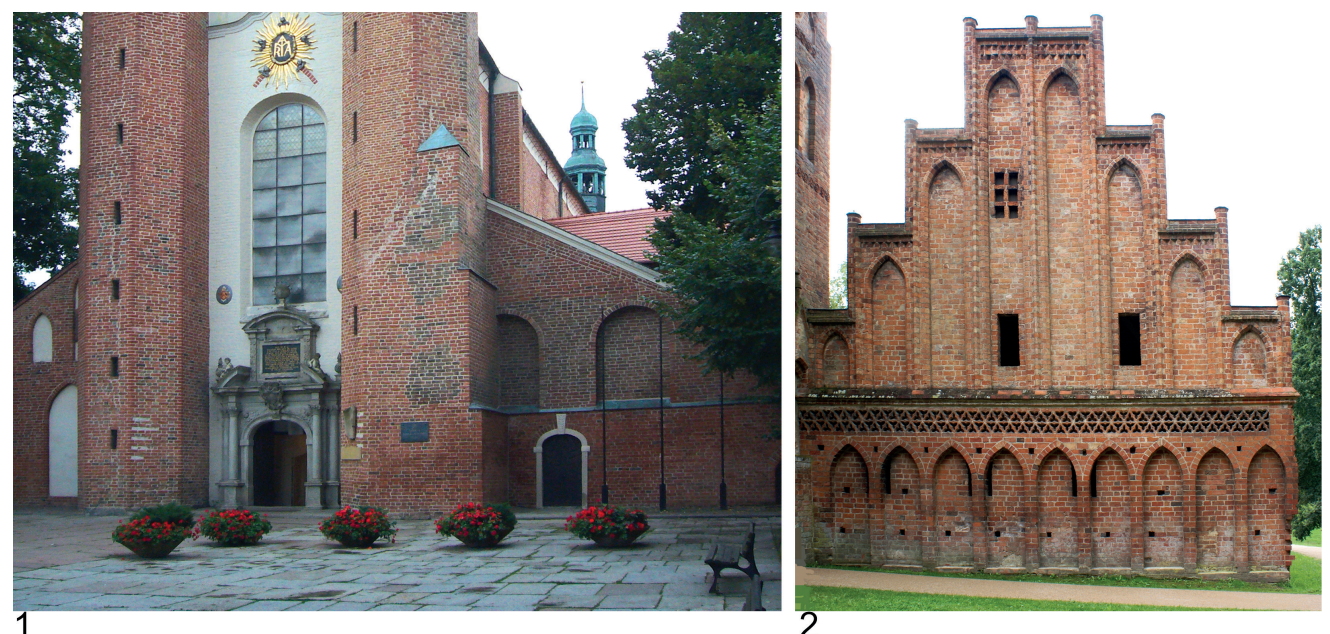

Fig. 8. Breweries by the cloistral buildings: 1 - relict in Oliwa, 2 - north wall of the building in Chorin, 2011, photo by E. Łużyniecka

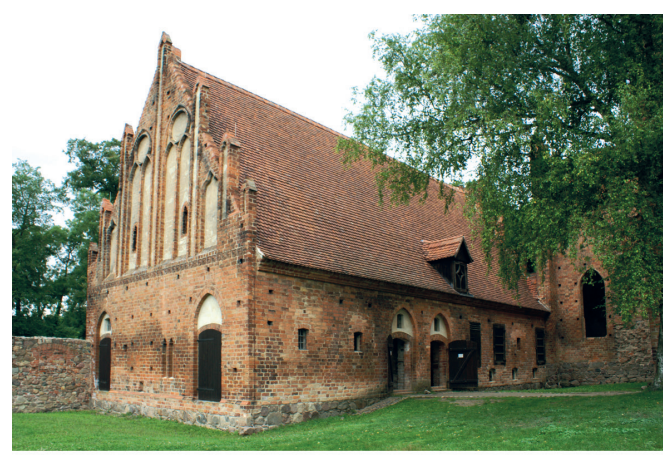

1

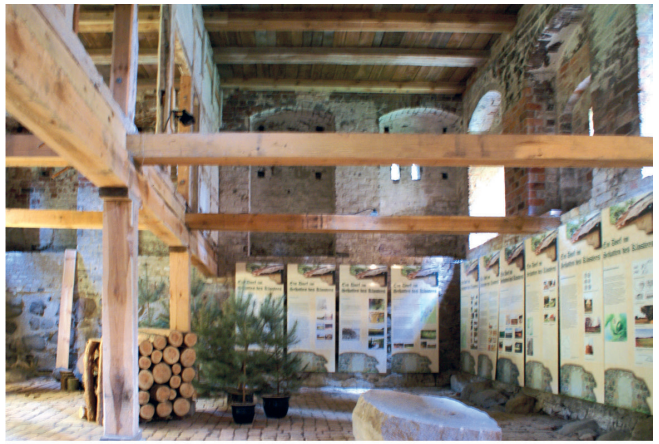

2

Fig. 9. Brewery in Chorin: 1 - south wall, 2 - interior, 2009, photo by E. Łużyniecka 
from the south facade described above. It has a tall triangular gable with tracery decoration. The inside of the brewery is a single room filled with timber structure. The basements are only under the south part of the brewery (Fig. 9).

\section{Summary}

Some conclusions regarding the breweries in Cistercian abbeys can be drawn on the basis of the presented analysis. The main observation is that there are very few original buildings of that type from the Middle Ages. If we assume that every abbey had at least one brewery, then their number should be at least close to a thousand. 343 monasteries were founded, mainly in France, from 1098, when the Cistercian order was founded, until 1153. In the following years, the Cistercians spread all over Europe and they reached Syria. Until the $14^{\text {th }}$ century, the number of abbeys grew to about $750[16$, p. 13].

There are several reasons why there are so few original Cistercian breweries. They were destroyed in the $16^{\text {th }}$ century when, as a result of the Reformation, some monasteries, especially German ones, were liquidated. On the other hand, in the times of the Counter-Reformation, in the $17^{\text {th }}$ and $18^{\text {th }}$ centuries, the complexes of monastic buildings in Austria, in Silesia, Bohemia, Hungary were extensively remodelled in the Baroque style. The breweries or even whole abbeys were also destroyed by the French Revolution - many abbeys were razed to the ground at the end of the $18^{\text {th }}$ century in France. A lot of destruction was connected also with the secularization of monasteries at the end of the $18^{\text {th }}$ and at the beginning of the $19^{\text {th }}$ century.

Another reason why there are so few original breweries in abbeys is their function, which required the constant use of fireplaces so their exposure to the danger of fire was obvious especially in the Middle Ages when breweries, just like other outbuildings, were rarely built of fireproof materials. A partial protection against fire was provided by their brick or stone walls and roofs covered with slate or clay tiles and such buildings have survived until today. Unfortunately, as can be concluded on the basis of relicts and iconography, they were usually half-timbered with brick infills. Sometimes, against all logic, they were built exclusively of flammable materials, such as wood and were covered with straw, reed or laths [7, p. 54].

Another conclusion drawn on the basis of the presented analyses regards the location of breweries within the monastery walls. Principally, they were built by watercourses which provided the water needed for the production of beer and which moved the wheels in the malthouse. The water was supplied to the breweries from the rivers flowing near monasteries in narrow canals (Fontenay, Doberan, Pelplin, Oliwa, Kamieniec Ząbkowicki) or wider mill streams (Lubiąż, Chorin). Before pumps were invented the water inside the breweries was carried in buckets. It cannot be ruled out, however, that other methods known from other branches of industry could also have been used e.g. lifting water in buckets placed in a treadmill.

There were two kinds of location of breweries in relation tothe church and the cloistral buildings. Some of them were built away from the centre of the abbey; they were usually bigger and they had beer storage rooms on lower levels (Fonteney, Lubiąż, Doberan). Other breweries were built by west wings of cloistral buildings and close to monastic churches 
(Oliwa, Chorin, Kamieniec Ząbkowicki). In such cases the beer produced in the brewery was stored in the monastic cellars.

Furthermore, it can be concluded on the basis of the conducted analyses that it was uncommon to have a malthouse, a brewhouse and a millhouse in a single structure (Doberan). Most often the individual stages of beer production took place in separate buildings, standing close to each other (Oliwa, Kamieniec Ząbkowicki, Pelplin). Sometimes breweries were built together with bakeries (Fonteney, Lubiąż). Such a combination was useful as in both cases grain was processed with the use of water and kilns.

The presented examples also confirmed the thesis known from studies according to which the architecture of monastic breweries, on the one hand, reflected the economic situation of the abbey and, on the other hand, the time and style as well as the region where it was established. The best example of this is the brewery in Doberan Abbey. Its structure and architectural details are repeated in other original buildings of the abbey from the Middle Ages.

Currently, the mediaeval breweries in Cistercian abbeys have a different status and function. Most often they have been listed as historic structures and converted from industrial or utility buildings to centres of culture or museums where the history of the abbey is presented. Often they host meetings and concerts.

Translated by Tadeusz Szatamacha

\section{References}

[1] Brzezowski W., Jagiełło M., Ogrody na Ślasku, Vol. 2., Barok, Oficyna Wydawnicza Politechniki Wrocławskiej, Wrocław 2017.

[2] Coppack G., The white monks. The Cistercians in Britain 1128-1540, Tempus, Stroud 2000.

[3] Fountains Abbey. Studley Royal, “The National Trust”, London 2000.

[4] Gooss G., Kloster Choerin. Gebrannte Geschichte-ein rundgang durch die Klosteranlage, Kloster Chorin, Eberswalde (without the issue date).

[5] Hebron S., Fonteney Life in a Monastery, PITKIN, (without the issue place) 2001.

[6] Klonder A., Napoje fermentacyjne w Prusach Królewskich w XVI-XVII wieku. Produkcja, import, konsumpcja, Ossolineum, Wrocław 1989.

[7] Klonder A., Browarnictwo w Prusach Królewskich (2 połowa XVI-XVII w.), Ossolineum, Wrocław-Wraszawa-Kraków-Gdańsk-Łódź 1983.

[8] Laboa J.M., Mnisi Zachodu i Wschodu. Historia monastycyzmu chrześcijańskiego, Carta Blanca, Warszawa 2009.

[9] Łużyniecka E., Architektura klasztorów cysterskich. Filie lubiąskie i inne cenobia śląskie, Oficyna Wydawnicza Politechniki Wrocławskiej Wrocław 2002.

[10] Łużyniecka E., Świechowski Z., Kunkel R., Architektura klasztorów cysterskich. Małopolskie filie opactwa Morimond, Oficyna Wydawnicza Politechniki Wrocławskiej, Wrocław 2008. 
[11] Łużyniecka E., Pelplin i Doberan. Architektura opactw cysterskich spokrewnionych filiacyjnie, Oficyna Wydawnicza Politechniki Wrocławskiej, Wrocław 2014, 794-802.

[12] Łużyniecka E., Le plus grand monument cistercien de Pologne: l'ancienne de Lubiaż, [in:] Mélanges cisterciens 2012: offerts par l'ARCCIS au Père Placide Vernet, moine de Cîteaux, pour son 90e anniversaire. BégrollesenMauges, Abbaye de Bellefontane 2012, 277-297.

[13] Łużyniecka E., Badania architektury francuskich klasztorów cysterskich w Obazine i Grosbot - etap wstępny, [in:] Dzieje i kultura Cystersów w Polsce, Vol. 1, M.Starzyński, D. Tabor (ed.), Wydawnictwo Towarzystwa Naukowego Societas Vistulana, Kraków 2016, 17-35.

[14] Piwek A., Architektura kościoła pocysterskiego w Oliwie od XII do XX wieku. Światynia zakonna bialych mnichów, Bernardinum, Pelplin 2006.

[15] Rutkowska-Płachcińska A., Urządzenia mlyńskie, przetwórstwo i wyrób artykułów spożywczych, organizacja sprzedaży, [in:] Historia kultury materialnej Polski w zarysie, Vol. II, Od XIII do XV wieku, Ossolineum, Wrocław-Warszawa-Kraków-Gdańsk 1978, 180-204.

[16] Warnatsch St., Zisterzienser - Abtei Lehnin. Von der askanischen Familien-Grablege zur Einrichtung evangelischer Nächstenhilfe, Verlag Langewiesche Nachf, Königstein 2008.

[17] Wyrwa A.M., Udział zakonu cysterskiego w ksztaltowaniu tożsamości kulturowej Europy ( $w$ świetle jego struktur organizacyjno-prawnych $w$ średniowieczu), [in:] Cistercium Mater Nostra. Tradycja - historia - kultura, M. Starzyński (ed.), Opactwo Cystersów w Mogile, Kraków 2009, Vol. III, 11-24. 